\title{
Effects of insulin and IGF-I on growth hormone- induced STAT5 activation in 3T3-F442A adipocytes
}

\author{
Yuchao Zhang ${ }^{1 \dagger}$, Yuantao Liư ${ }^{2 \dagger}$, Xia Li ${ }^{1}$, Weina Gao ${ }^{1}$, Wenjie Zhang ${ }^{2}$, Qingbo Guan ${ }^{3}$, Jing Jiang ${ }^{4}$,
} Stuart J Frank ${ }^{4,5}$ and Xiangdong Wang ${ }^{1,6^{*}}$

\begin{abstract}
Background: Growth hormone $(\mathrm{GH})$ and insulin signaling pathways are known important regulators of adipose homeostasis. The cross-talk between GH and insulin signaling pathways in mature adipocytes is poorly understood.

Methods: In the present study, the impact of insulin on GH-mediated signaling in differentiated 3T3-F442A adipocytes and primary mice adipocytes was examined.

Results: Insulin alone did not induce STAT5 tyrosine phosphorylation, but enhanced GH-induced STAT5 activation. This effect was more pronounced when insulin was added 20 min prior to $\mathrm{GH}$ treatment. The above results were further confirmed by in vivo study, showing that insulin pretreatment potentiated GH- induced STAT5 tyrosine phosphorylation in visceral adipose tissues of C57/BL6 mice. In addition, our in vitro results showed that IGF-I had similar potentiating effect as insulin on GH-induced STAT5 activation. In vitro, insulin and IGF-I had an additive effect on $\mathrm{GH}$ - induced MAPK activation.

Conclusion: These results indicate that both insulin and IGF-I specifically potentiated GH mediated STAT5 activation in mature adipose cells. These findings suggest that insulin and $\mathrm{GH}$, usually with antagonistic functions, might act synergistically to regulate some specific functions in mature adipocytes.
\end{abstract}

Keywords: GH, Insulin, 3T3-F442A adipocyte, IGF-I

\section{Background}

Growth hormone (GH) is a 22-kDa peptide that plays important roles in regulation of growth and metabolism $[1,2]$. Binding of GH to its receptor (GHR), a transmembrane glycoprotein member of the cytokine receptor superfamily [2], results in receptor dimerization and rapid activation of the tyrosine kinase Janus kinase 2 (JAK2) [3]. This in turn initiates a variety of signaling cascades, including the signal phosphatidylinositol 3-kinase (PI3K) and mitogen-activated protein kinases (MAPK/ERK) pathways [4]. In addition to PI3K and MAPK, GH has been shown to activate the STATs mediated signaling pathways

\footnotetext{
* Correspondence: xdongw@sdu.edu.cn

${ }^{\dagger}$ Equal contributors

'The Institute of Cell Biology, Shandong University School of Medicine, Jinan 250012, China

${ }^{6}$ Key Laboratory of Protein Sciences for Chronic Degenerative Diseases in Universities of Shandong (Shandong University), Jinan 250033, China Full list of author information is available at the end of the article
}

[2]. In particular, STAT5a and $\mathrm{b}$ are believed to be the major downstream targets of GH [5]. STAT5a and b are encoded by different genes, however, they share $>90 \%$ amino acid identity [6]. Upon GH stimulation, STAT5 were recruited to GHR and subsequently phosphorylated on tyrosine residues [6]. Tyrosine phosphorylated STAT5s dimerize and translocate to the nucleus where it binds to specific DNA elements to modulate gene expression in fat tissue in response to GH [6-10]. Studies on the identification of STAT5 target genes in adipocytes indicate that STAT5 modulate gene expression in a manner that favors a reduction in lipid synthesis and/or storage and an increase in lipid release [11-13]. In rat pre-adipocytes, the ability of GH to inhibit expression of aP2, a fatty acidbinding protein in adipocytes, is largely dependent on the GH-induced activation of STAT5 [14]. Growth hormone stimulated lipolysis has been confirmed by evidence from STAT5a and b knockout mice [15].

\section{Biomed Central}

(c) 2013 Zhang et al.; licensee BioMed Central Ltd. This is an Open Access article distributed under the terms of the Creative Commons Attribution License (http://creativecommons.org/licenses/by/2.0), which permits unrestricted use, distribution, and reproduction in any medium, provided the original work is properly cited. 
Insulin is the key regulatory hormone in control of glucose homeostasis and metabolism in muscle and adipose tissue [16]. Insulin acts via binding to its cell surface receptor, and subsequently induces the phosphorylation of insulin receptor substrate proteins (IRSs) [17]. Downstream of IRSs, the major signal pathways activated by insulin are PI3K and MAPK pathways [17,18]. In adipose tissue, insulin was shown to increase the adipocyte size through activation of PI3K [18].

The above studies indicate that both $\mathrm{GH}$ and insulin play important roles in regulation of adipocyte functions. Moreover, GH and insulin signaling pathways share some downstream elements. However, the interactions and signal integration between these two signaling pathways in mature adipocytes is poorly understood. In the present study, we determined the effects of insulin on GH mediated signaling pathways in adipocytes both in vitro and in vivo.

\section{Results}

Effects of GH, insulin and IGF-I on STAT5 and MAPK activation in differentiated 3T3-F442A adipocytes

3T3-F442A pre-adipocytes were induced to differentiate as previously described [19], and cell differentiation was confirmed by Oil-Red-O staining. Differentiated 3T3F442A cells were stimulated with GH, insulin or IGF-1 respectively. Results of western blot showed that GH induced STAT5 tyrosine phosphorylation in differentiated 3T3-F442A cells in dose- and time- dependent manners (Figure 1A,B). A maximum STAT5 phosphorylation was induced by $125 \mathrm{ng} / \mathrm{mL}$ GH for $15 \mathrm{~min}$ (Figure 1D,E). Similarly, GH also induced MAPK activation in dose- and time- dependent manners (Figure 1A,B,F,G). A maximum MAPK activation was induced by $125 \mathrm{ng} / \mathrm{mL}$ GH for $10 \mathrm{~min}$.

Under same conditions, insulin (200 nM) or IGF-I (100 $\mathrm{ng} / \mathrm{mL}$ ) induced maximum MAPK activation at $10 \mathrm{~min}$ (Figure $1 \mathrm{C}, \mathrm{H}$ ) or $5 \mathrm{~min}$ (Figure 1C,I) respectively. Similarly, Insulin and IGF-I also induced the phosphorylation of AKT (Figure 1C,J,K). However, Insulin and IGF-I did not induce detectable STAT5 tyrosine phosphorylation.

\section{Effects of insulin on GH-induced STAT5 and MAPK activation in differentiated 3T3-F442A adipocytes}

Differentiated 3T3-F442A cells were treated with GH $(0,5$, $25,50$ and $125 \mathrm{ng} / \mathrm{mL})$ or co-treated with insulin $(200 \mathrm{nM})$ for $10 \mathrm{~min}$, or pretreated with $200 \mathrm{nM}$ insulin for $20 \mathrm{~min}$ followed by addition of GH for additional $10 \mathrm{~min}$. Results showed that simultaneous insulin treatment significantly increased STAT5 phosphorylation compared to $\mathrm{GH}$ alone (Figure 2A,C). Insulin pretreatment for 20 min further increased GH-induced STAT5 phosphorylation compared to $\mathrm{GH}$ and insulin co-treatment (Figure 2A,D). As insulin at high concentration may activate IGF-I receptor, thus we examined the effects of insulin at lower doses (close to physiological concentrations) on GH-induced STAT5 activation. As shown in Figure 3A/B, insulin at lower doses (10 $\mathrm{nM}$ and $100 \mathrm{nM}$ ) also enhanced GH-induced STAT5 phosphorylation (Figure 3A,B).

Under same conditions, the effects of insulin on GHinduced MAPK activation were examined. Simultaneous insulin $(200 \mathrm{nM})$ treatment had an additive effect on GH- $(5 \mathrm{ng} / \mathrm{mL}, 25 \mathrm{ng} / \mathrm{mL}$ ) induced MAPK activation (Figures 2B,E). Insulin (200 nM) pretreatment (insulin was added $20 \mathrm{~min}$ prior to $\mathrm{GH}$ ) did not influence $\mathrm{GH}$ induced MAPK activation (Figure 2B,F).

\section{Insulin enhanced GH-induced STAT5 activation in primary} adipocytes from C57/BL6 mice

C57/BL6 mice were pretreated with or without insulin ( $2 \mu \mathrm{mol} / \mathrm{kg} . \mathrm{BW})$ injection for $20 \mathrm{~min}$, and then were injected with GH (50 $\mu \mathrm{g} / \mathrm{kg} . \mathrm{BW}) .10 \mathrm{~min}$ after GH injection, mice were sacrificed, and visceral adipose tissues were isolated for western blot analysis. Insulin pretreatment increased STAT5 phosphorylation in adipose tissues by $60 \%$ as compared to mice treated with $\mathrm{GH}$ alone (Figure 3C,D). GH induced MAPK activation was not influenced by insulin pretreatment (data not shown).

\section{Effects of IGF-I on GH-induced STAT5 and MAPK activation in differentiated 3T3-F442A adipocytes}

As IGF and insulin have similarities in their mode of signaling and functions, thus we tested whether IGF-I has similar effects as insulin on GH mediated signaling in mature adipocytes. Differentiated 3T3-F442A cells were treated with $\mathrm{GH}$ alone or co-treated with IGF-I $(100 \mathrm{ng} / \mathrm{mL})$ for $10 \mathrm{~min}$; or pretreated with IGF-I $(100 \mathrm{ng} / \mathrm{mL})$ for $20 \mathrm{~min}$ followed by GH stimulation for additional $10 \mathrm{~min}$. Simultaneous IGF-I treatment enhanced GH $(5 \mathrm{ng} / \mathrm{mL})$ induced STAT5 and had an additive effect on GH induced MAPK activation (Figure 4A,B,D,F). IGF-I pretreatment for $20 \mathrm{~min}$ enhanced STAT5 activation induced by $\mathrm{GH}$ of varying concentrations (GH 5, 25, $50 \mathrm{ng} / \mathrm{mL}$ ) (Figure 4C,E); but did not change the profile of MAPK (Figure 4A,C,G).

\section{Discussion}

Both growth hormone and insulin play essential roles in control of development and metabolism. At the whole body level, the actions of these two hormones are highly coordinated. For instance, in the early postprandial phase, increase in insulin secretion and decrease in GH secretion favors the disposal of glucose and fat; whereas in the post-absorptive phase, increase in $\mathrm{GH}$ secretion and decrease in insulin promote lipolysis and fat oxidation [20]. At the cellular level, however, the functions of $\mathrm{GH}$ and insulin are distinct and usually antagonistic. In adipocytes, the direct interactions between these two hormones are not well understood. 
B

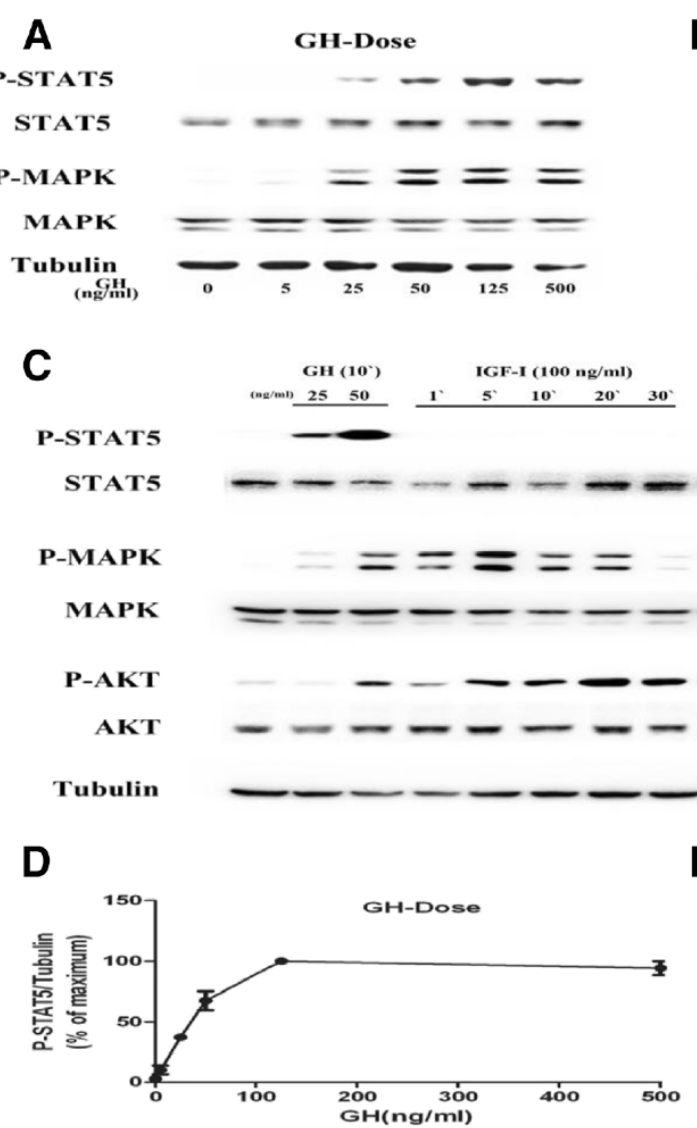

E

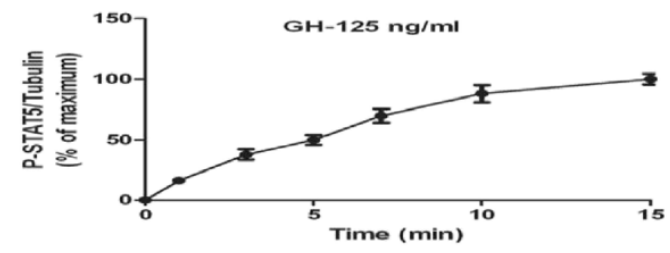

$\mathbf{F}$

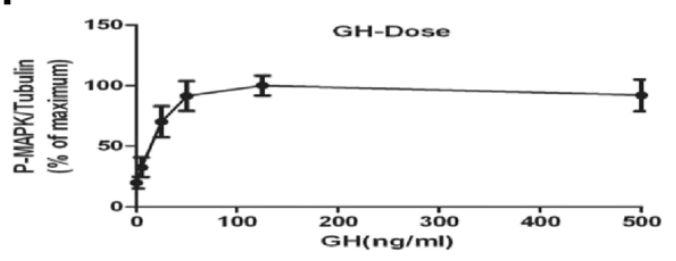

G

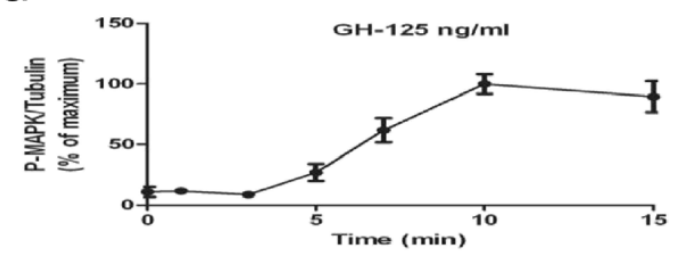

H

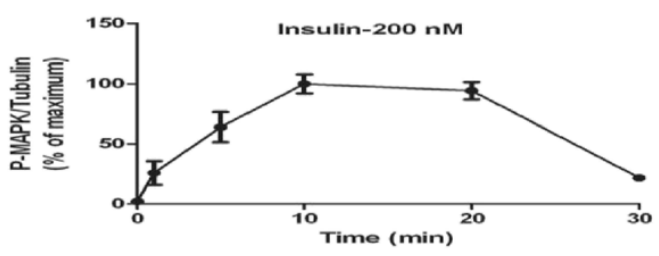

I

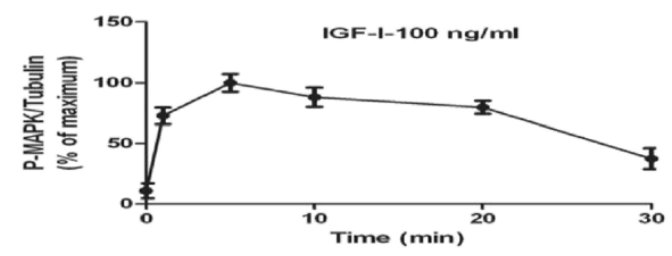

J

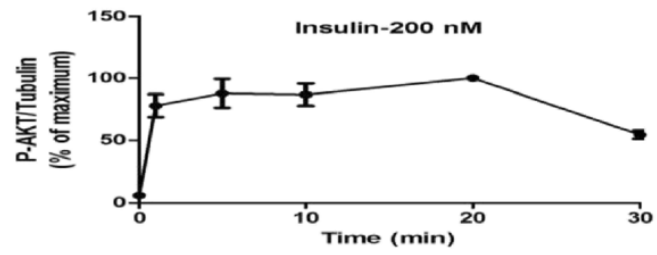

$\mathbf{K}$

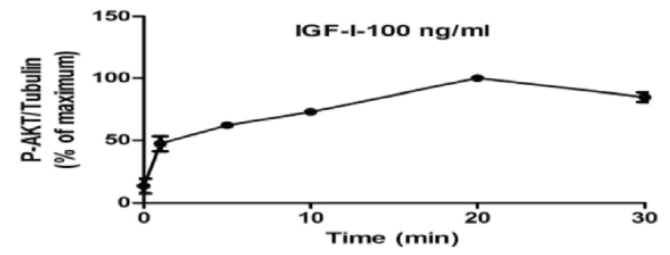

Figure 1 (See legend on next page.) 
(See figure on previous page.)

Figure $1 \mathrm{GH}$ and insulin- induced STAT5 and MAPK activation in differentiated 3T3-F442A adipocytes. STAT5, MAPK and AKT activations were analyzed by Western blot using specific antibodies against phosphorylated forms of STAT5, MAPK and AKT (A-C). Densitometric analysis of the results from Western Blots (D-K). A, D and F, STAT5 and MAPK activation induced by GH at various concentrations for 10 min $(n=4)$. B, E and G, STAT5 and MAPK activation induced by a single dose of GH $(125 \mathrm{ng} / \mathrm{ml})$ for indicated times $(\mathrm{n}=4)$. C, $\mathbf{H}$ to $\mathbf{K}$, STAT5 MAPK and AKT activation induced by IGF-I $(100 \mathrm{ng} / \mathrm{ml})$ or insulin $(200 \mathrm{nM})(\mathrm{n}=3)$.

Previous studies indicated that GH could induce lipolysis in adipose tissue [10,12], which is associated with STAT5 activation. In the present study, we demonstrated that GH induced STAT5 activation in dose- and timedependent manners in mature 3T3-F442A adipocytes. In addition, our results showed that insulin alone had no detectable effect on STAT5 tyrosine phosphorylation, but significantly enhanced GH-induced STAT5 tyrosine phosphorylation. Our results suggested that insulin had a potentiating effect on GH induced STAT5 activation.

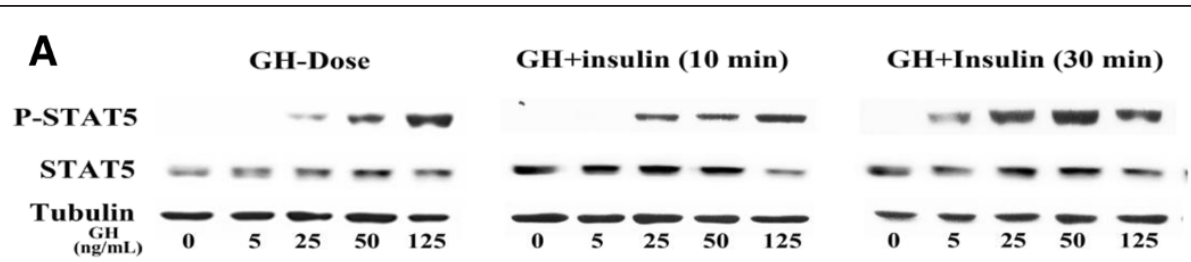

B

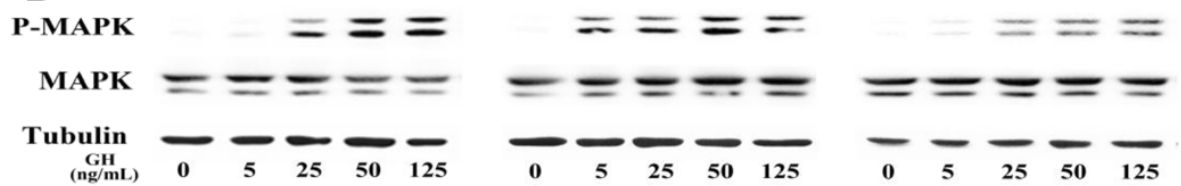

C

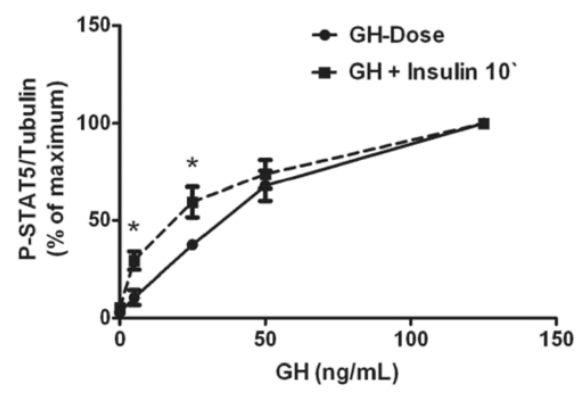

E

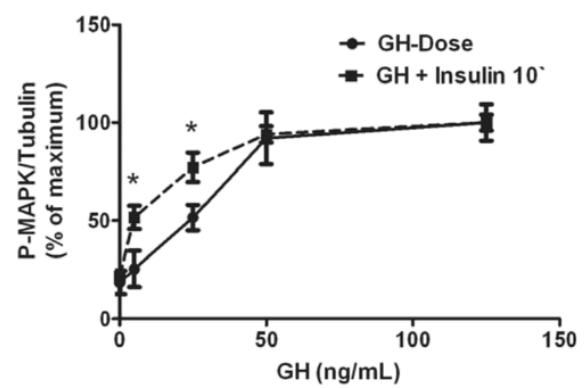

D

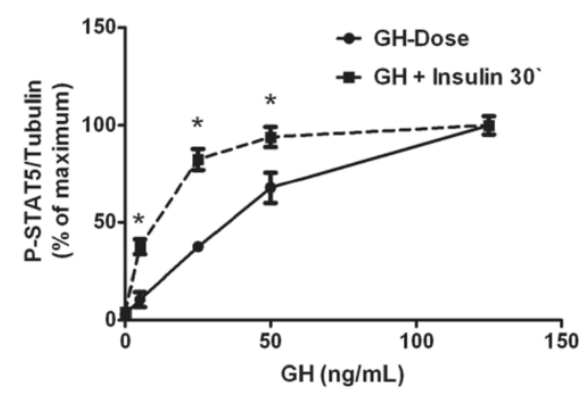

$\mathbf{F}$

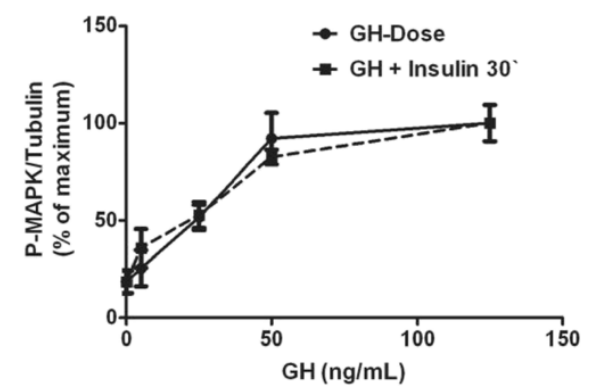

Figure 2 Effects of insulin on GH- induced STAT5 and MAPK activation in differentiated 3T3-F442A adipocyte cells. A, B, representative results of Western blot $(n=4)$. C, GH versus $\mathrm{GH}$ plus insulin (10 min) on STAT5 activaion $(n=6)$. D, GH versus insulin pretreatment (insulin was added 20 min prior to $\mathrm{GH}$ ) on STAT5 activation $(n=6)$. $\mathbf{E}, \mathbf{F}, \mathrm{GH}$ versus $\mathrm{GH}$ plus insulin on MAPK activation. ${ }^{*} p<0.05$, vs. GH alone. 


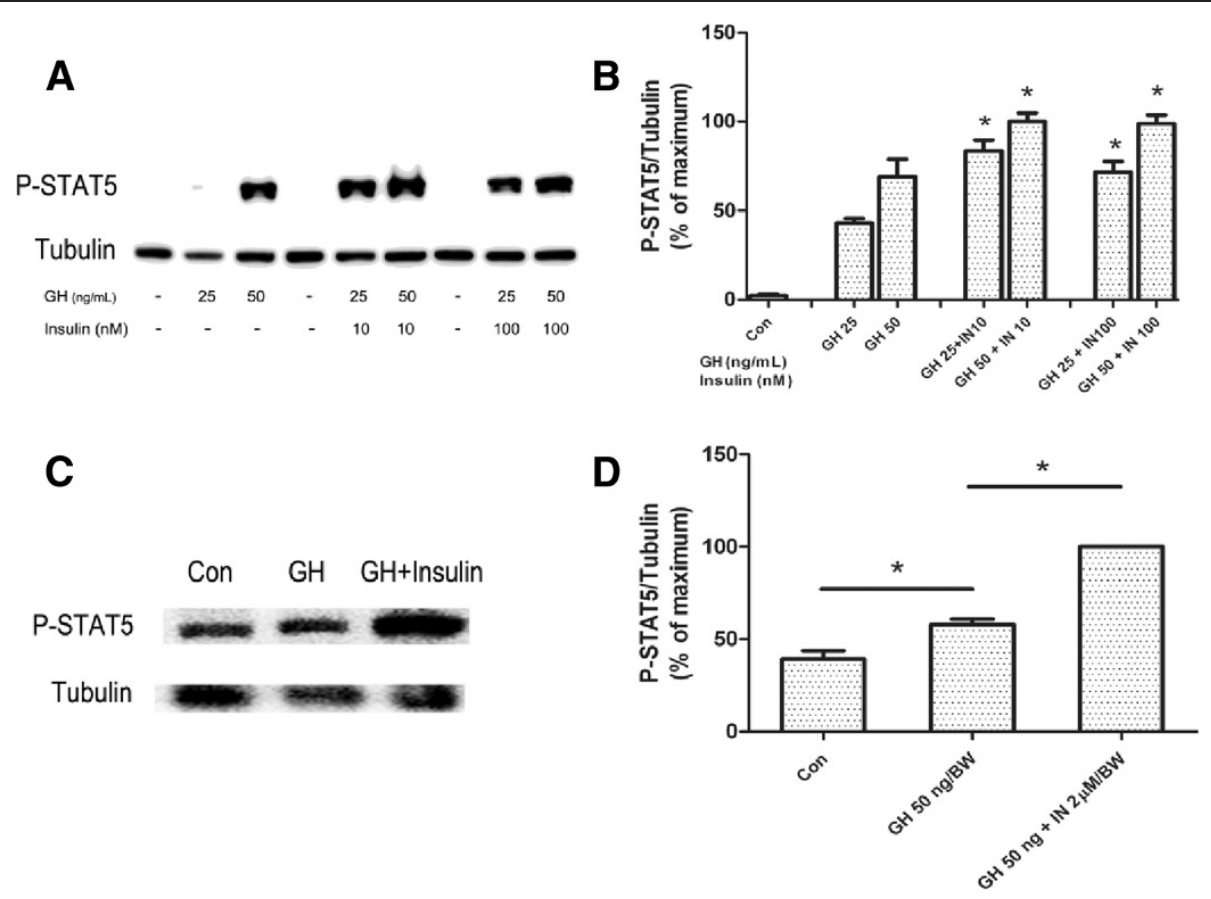

Figure 3 Insulin pretreatment on GH induced STAT5 activation in vitro (A, B) and in vivo (C,D). A, B, pretreatment with $10 \mathrm{nM}$ or $100 \mathrm{nM}$ insulin (insulin was added 20 min prior to GH) on GH- induced STAT5 activation in differentiated 3T3-F442A cells $(n=4)$. C, $D$, visceral adipose

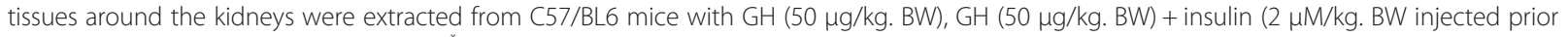
20 min to $\mathrm{GH}$ ) or saline injection $(n=5) .{ }^{*} p<0.05, \mathrm{GH}$ alone vs.control; $\mathrm{GH}+$ insulin vs. $\mathrm{GH}$ alone.

To determine whether the potentiating effect of insulin is specific for STAT5, we next examined the effect of insulin on GH induced MAPK activation. Our results showed insulin had an additive effect rather than potentiating effect on GH-induced MAPK activation.

To confirm our in vitro results, we conducted animal experiments using C57/BL6 mice. As female mice have relatively more stable plasma $\mathrm{GH}$ levels [21], therefore female C57/BL6 mice were used in the present study. The results showed that insulin enhanced $\mathrm{GH}$-induced STAT5 tyrosine phosphorylation in primary mice adipocytes, but had no obvious effect on GH induced MAPK activation (result did not show).

As IGF-I and insulin have similarities in their mode of signaling and functions, thus we tested whether IGF-I has similar effects as insulin on GH mediated signaling in mature adipocytes. Similar to insulin, IGF-I showed a potentiating effect on $\mathrm{GH}$ - induced STAT5 activation but had an additive effect on GH- induced MAPK activation. These findings suggested insulin and IGF-I might produce some common signals, which specifically potentiate GHinduced STAT5 tyrosine phosphorylation. Interestingly, a previous study has shown that chronic GH treatment of differentiated 3T3-L1 adipocytes reduces insulinstimulated 2-deoxyglucose (DOG) uptake and activation of AKT, leading to insulin resistance [22]. So far, the acute effect and significance of GH on insulin signaling have not been well documented.

To date, the mechanism behind the differential effects of insulin on GH induced STAT5 and MAPK activation is unclear. There is evidence showing that GHR, insulin receptor, IGF-I receptor were co-localized in lipid rafts [23-26]. It is possible that lipid raft may provide a platform for the interactions between these signaling molecules.

\section{Conclusions}

In summary, our results showed that insulin specifically potentiates $\mathrm{GH}$-induced STAT5 activation in mature adipocytes both in vitro and in vivo. These findings suggested that insulin and $\mathrm{GH}$, usually with antagonistic functions, might act synergistically to regulate some specific functions in mature adipocytes. The downstream biological events and clinical relevance of the interactions between insulin and $\mathrm{GH}$ need further investigation.

\section{Methods}

\section{Materials}

Recombinant human GH was kindly provided by Eli Lilly \& Co. (Indianapolis, IN). Recombinant human insulin was from Sigma (St. Louis, MO, USA). IGF-I was purchased 

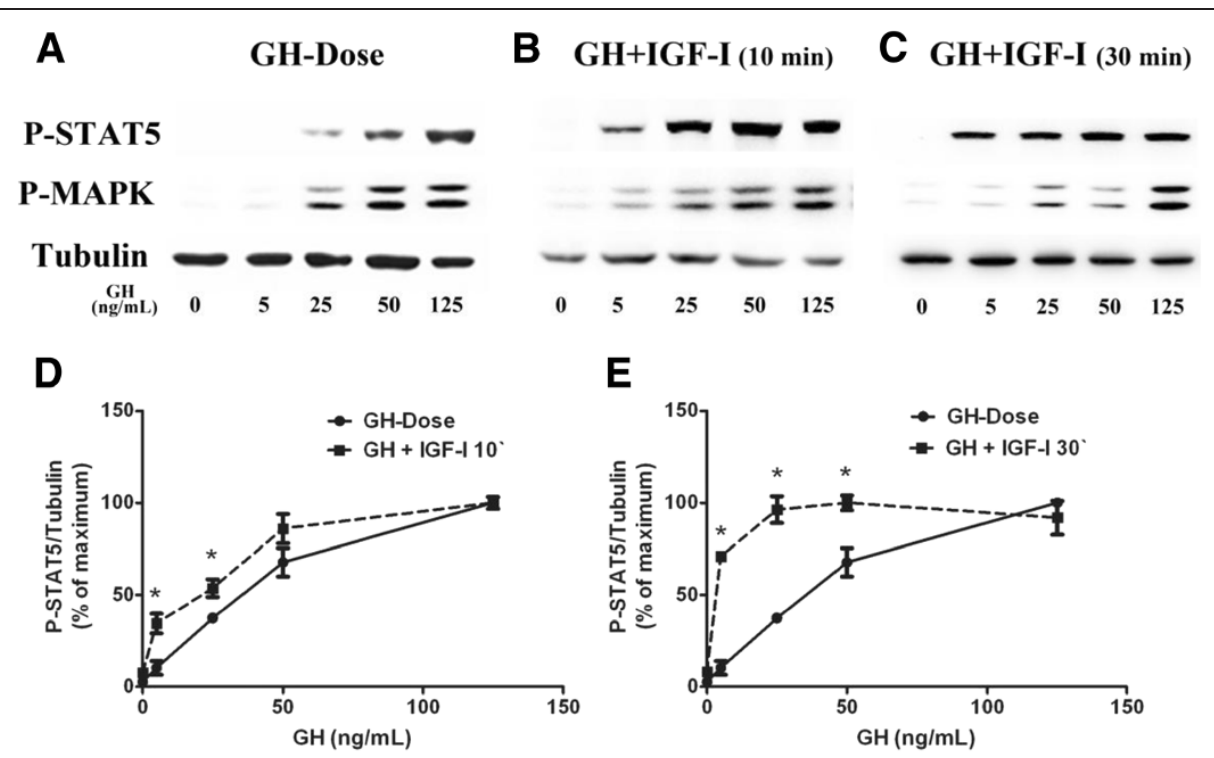

E
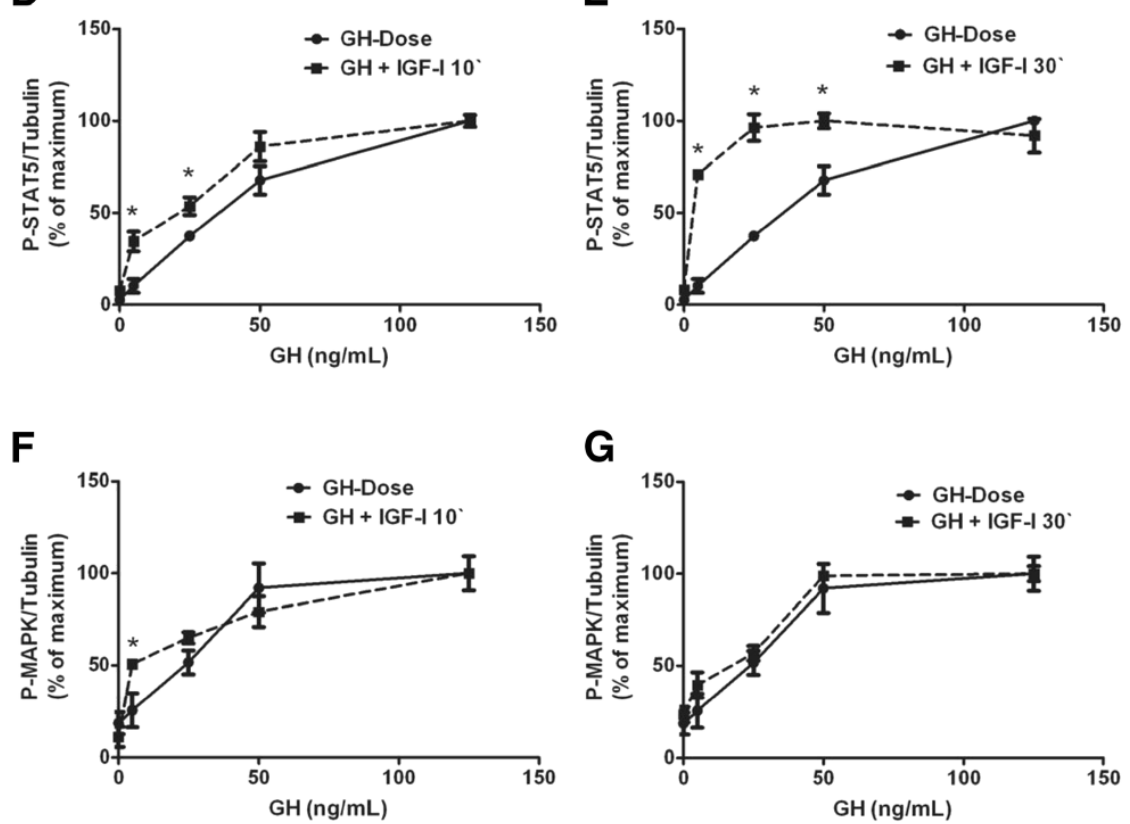

Figure 4 Effects of IGF-I on GH -induced STAT5 and MAPK phosphorylation in differentiated 3T3-F442A adipocytes. A, B, C, representative results of Western blot $(n=4)$. D, GH versus GH plus IGF-I $(10 \mathrm{~min})$ on STAT5 activation $(n=4)$. $\mathbf{E}, \mathrm{GH}$ versus IGF-I preatreatment (IGF-I was added 20 min prior to $\mathrm{GH}$ ) on STAT5 activation $(n=4)$. F, GH versus GH plus IGF-1 (10 min) on MAPK activation $(n=4)$. $G, G H$ versus IGF-I pretreatment (IGF-I was added 20 min prior to GH) on MAPK activation $(n=4) .{ }^{*} p<0.05$, vs. GH alone.

from NovozymesGroPep Ltd (Thebarton, South Australia, Australia). Cell culture medium and fetal bovine serum (FBS) were from Hyclone (ThermoScientific, Inc., Illinois, USA). All other reagents were purchased from Sigma.

\section{Antibodies}

Polyclonal antibody against phospho-tyrosine-STAT5 was purchased from Invitrogen (CA, USA); polyclonal antibody against STAT5 was purchased from Santa Cruz Biotechnology, Inc (Santa Cruz, CA); polyclonal antibody against phospho- ERK (recognizing the dually phosphorylated Thr-183 and Tyr-185 residues corresponding to the active forms of ERK1 and ERK2) was from Promega (Madison, WI); affinity-purified polyclonal antibody against ERK (recognizing both ERK1 and ERK2) was from Upstate Biotechnology (Lake Placid, NY); polyclonal antibody against AKT and phospho-AKT (S473) were purchased from Cell Signaling Technology (Beverly, MA, USA) and monoclonal antibody against $\alpha$-tubulin was from Sigma. All secondary antibodies were purchased from ZhongShanJinQiao (China).

\section{Cell culture}

3T3-F442A cells, kindly provided by Drs. H. Green (Harvard University, Boston, MA) and C. Carter-Su (University of Michigan, Ann Arbor, MI), were cultured and induced to differentiate as described previously [19]. In brief, cells were cultured in Dulbecco's modified Eagle's medium containing (DMEM) $4.5 \mathrm{~g} / \mathrm{L}$ glucose, supplemented with $10 \%$ new born calf serum (NCS), 50 $\mu \mathrm{g} / \mathrm{mL}$ streptomycin and $100 \mathrm{U} / \mathrm{mL}$ penicillin until they reached confluence. To induce differentiation, confluent cells were cultured in DMEM containing 10\% FBS with $5 \mu \mathrm{M}$ insulin. The differentiation medium was refreshed every other day. After 3 times of medium changes, insulin was removed from the culture medium. Cells were cultured with DMEM containing 10\% FBS, and the medium was refreshed every other day. After 12 days, 
approximately $80 \%$ cells were differentiated into adipocytes as confirmed by Oil Red- O staining (not shown).

\section{Cell stimulation}

Differentiated F442A adipocytes were starved in culture medium containing $0.5 \%(\mathrm{w} / \mathrm{v})$ bovine serum albumin (BSA) for $16 \mathrm{~h}$ before stimulation. All the stimulations were carried out at $37^{\circ} \mathrm{C}$ in DMEM with $0.5 \%$ BSA. For dose-response experiments, serum-starved cells were treated with: $\mathrm{GH}(0,5,25,50,125$, or $500 \mathrm{ng} / \mathrm{mL})$ for $10 \mathrm{~min}$; $\mathrm{GH}(0,5,25,50$, or $125 \mathrm{ng} / \mathrm{mL})$ plus $200 \mathrm{nM}$ insulin for $10 \mathrm{~min}$; $\mathrm{GH}$ in the presence of insulin (10, 100 or $200 \mathrm{nM}$ ) for $30 \mathrm{~min}$ (added $20 \mathrm{~min}$ prior to $\mathrm{GH}$ ); $\mathrm{GH}$ plus $100 \mathrm{ng} / \mathrm{mL}$ IGF-I for $10 \mathrm{~min}$; or GH plus IGF-I for $30 \mathrm{~min}$ (100 ng/mL IGF-I was added $20 \mathrm{~min}$ prior to $\mathrm{GH}$ ). For time course experiments, serum-starved cells were treated with: $\mathrm{GH}(125 \mathrm{ng} / \mathrm{mL})$ for different periods $(0,1,3,5,7$, 10 or $15 \mathrm{~min})$, IGF-I $(100 \mathrm{ng} / \mathrm{mL})$ or insulin $(200 \mathrm{nM})$ for different periods $(0,1,5,10,20$ or $30 \mathrm{~min})$. Stimulation was end by washing cells twice with an ice-cold phosphate-buffered saline (PBS) in presence of $0.4 \mathrm{mM}$ sodium orthovanadate.

\section{Animal experiments}

Female C57/BL6 mice, aged 12-weeks, weighing 20-24 g, were purchased from the Experimental Animal Center of Shandong University. Animal experiments were carried out according to the 'Principles of laboratory animal care' established by the National Institutes of Health, and approved by the 'Animal Care and Use Committee' of the Shandong University (Number: MECSDUMS 2011055). Mice were maintained under diurnal lightning conditions at $25^{\circ} \mathrm{C}$ with free access to tap water and food. Mice were randomly divided into three groups: the "control group", "GH group", and "GH + insulin group". $\mathrm{GH}$ group mice were injected intraperitoneally (i.p.) with $50 \mu \mathrm{g}$ of $\mathrm{GH}$ per $\mathrm{kg}$ of body weight (BW) in $0.2 \mathrm{ml}$ saline for $10 \mathrm{~min}$ before sacrifice. $\mathrm{GH}+$ insulin group mice were first injected i.p. with $2 \mu \mathrm{mol}$ insulin $/ \mathrm{kg}$.BW in $0.1 \mathrm{~mL}$ saline and $20 \mathrm{~min}$ later with $50 \mu \mathrm{g} / \mathrm{kg} . \mathrm{BW} \mathrm{GH}$ in $0.1 \mathrm{~mL}$ saline before sacrifice $10 \mathrm{~min}$ thereafter. The control mice were injected with saline. Prior to injection, all mice were fasted overnight. After treatment, mice were sacrificed by decapitation under anesthesia with $10 \%$ chloral hydrate. Visceral adipose tissues around the kidneys were collected for western blot analysis.

\section{Western blotting}

Cells or adipose tissues were harvested and solubilized for $60 \mathrm{~min}$ on ice in lysis buffer $(150 \mathrm{mM} \mathrm{NaCl}, 10 \%$ (vol/vol) glycerol, 50 mM Tris- $\mathrm{HCl}$ (pH 7.3), 1 mM EDTA, $1.5 \mathrm{nM}$ magnesium chloride, $10 \mathrm{mM}$ sodium pyrophosphate,
2 mMphenylmethylsulphonyl fluoride (PMSF), $100 \mathrm{mM}$ sodium fluoride, $1 \mathrm{mM}$ sodium orthovanadate, with $1 \%$ (wt/vol) Triton X-100. Protein concentration was determined by Bradford method (BCA protein assay reagent, Beyotime, China). Equal amounts of protein were separated by SDS-polyacrylamide gel electrophoresis and electro-transferred onto a polyvinylidenedifluoride (PVDF) membrane. Proteins were detected by immunoblotting imaged with ECL chemiluminescence (Amersham Biosciences, Buckinghamshire, England).

\section{Densitometric analysis}

Chemiluminescence signals were detected with a luminoimage analyzer Fluor Chem E (Alpha View, Santa Clara, CA 95051). Densitometric quantification of images exposed in the linear range was performed using an image analysis program, Image J (developed by W. S. Rasband, Research Services Branch, National Institute of Mental Health, Bethesda, MD).

\section{Statistical analysis}

All data are expressed as mean \pm SEM. Differences between groups were examined by Student's $t$ test or ANOVA using SPSS17.0 software. A value of $p<0.05$ was considered statistically significant.

\section{Competing interests}

The authors declare that they have no competing interests.

\section{Authors' contributions}

YCZ and YTL conducted research and wrote paper. WNG and QBG performed the statistical analysis. XL, JJ and WJZ helped in conducting research. XDW and SJF designed the research. All authors read and approved the final manuscript.

\section{Acknowledgements}

This work was supported by National Natural Science Foundation of China (NSFC, funding numbers are 30870922, 81170814), Shandong Natural Science Foundation (NSFC, funding number is 2009ZRB02545), the U.S. National Institutes of Health R01DK46395 (to S.J.F.), and the Education Department of China for PhD program (funding number is 20100131110037).

\section{Author details}

${ }^{1}$ The Institute of Cell Biology, Shandong University School of Medicine, Jinan 250012, China. ${ }^{2}$ The Second Hospital of Shandong University, Jinan 250033, China. ${ }^{3}$ Shandong Provincial Hospital, affiliated to Shandong University, Jinan 250021, China. ${ }^{4}$ Department of Medicine, Division of Endocrinology,

Diabetes, and Metabolism, University of Alabama at Birmingham, Birmingham, AL 35294, UK. ${ }^{5}$ Endocrinology Section, Medical Service, Veterans Affairs Medical Center, Birmingham, AL 35233, UK. ${ }^{6}$ Key Laboratory of Protein Sciences for Chronic Degenerative Diseases in Universities of Shandong (Shandong University), Jinan 250033, China.

Received: 27 February 2013 Accepted: 18 April 2013 Published: 30 April 2013

\section{References}

1. Isaksson O, Eden S, Jansson J: Mode of action of pituitary growth hormone on target cells. Annu Rev Physiol 1985, 47:483-499.

2. Ji S, Frank SJ, Messina JL: Growth hormone-induced differential desensitization of STAT5, ERK, and Akt phosphorylation. J Biol Chem 2002, 277:28384-28393. 
3. Williams JG: STAT signalling in cell proliferation and in development. Curr Opin Genet Dev 2000, 10:503-507.

4. Anderson NG: Growth hormone activates mitogen-activated protein kinase and 56 kinase and promotes intracellular tyrosine phosphorylation in 3T3-F442A preadipocytes. Biochem J 1992, 284:649.

5. Ram PA, Park SH, Choi HK, Waxman DJ: Growth hormone activation of Stat 1, Stat 3, and Stat 5 in rat liver. Differential kinetics of hormone desensitization and growth hormone stimulation of both tyrosine phosphorylation and serine/threonine phosphorylation. J Biol Chem 1996, 271:5929-5940.

6. Balhoff JP, Stephens JM: Highly specific and quantitative activation of STATs in 3T3-L1 adipocytes. Biochem Biophys Res Commun 1998, 247:894-900.

7. Story DJ, Stephens JM: Modulation and lack of cross-talk between signal transducer and activator of transcription 5 and suppressor of cytokine signaling-3 in insulin and growth hormone signaling in 3T3-L1 adipocytes. Obesity 2012, 14:1303-1311.

8. Hogan JC, Stephens JM: The regulation of fatty acid synthase by STAT5A. Diabetes 2005, 54:1968-1975.

9. Zvonic S, Story DJ, Stephens JM, Mynatt RL: Growth hormone, but not insulin, activates STAT5 proteins in adipocytes in vitro and in vivo. Biochem Biophys Res Commun 2003, 302:359-362.

10. Asada N, Takahashi Y, Wada M, Naito N, Uchida H, Ikeda M, Honjo M: GH induced lipolysis stimulation in 3T3-L1 adipocytes stably expressing hGHR: analysis on signaling pathway and activity of $20 \mathrm{~K} \mathrm{hGH}$. Mol Cell Endocrinol 2000, 162:121-129.

11. Richard AJ, Stephens JM: Emerging roles of JAK-STAT signaling pathways in adipocytes. Trends Endocrinol Metab 2011, 22:325-332.

12. Milocco LH, Haslam JA, Rosen J, Seidel HM: Design of conditionally active STATs: insights into STAT activation and gene regulatory function. Mol Cell Biol 1999, 19:2913-2920.

13. Kazansky AV, Kabotyanski EB, Wyszomierski SL, Mancini MA, Rosen JM: Differential Effects of Prolactin andsrc/abl Kinases on the Nuclear Translocation of STAT5B and STAT5A. J Biol Chem 1999, 274:22484-22492.

14. Richter $\mathrm{H}$, Albrektsen $\mathrm{T}$, Billestrup $\mathrm{N}$ : The role of signal transducer and activator of transcription 5 in the inhibitory effects of $\mathrm{GH}$ on adipocyte differentiation. J Mol Endocrinol 2003, 30:139-150.

15. Fain JN, Ihle JH, Bahouth SW: Stimulation of lipolysis but not of leptin release by growth hormone is abolished in adipose tissue from Stat5a and b knockout mice. Biochem Biophys Res Commun 1999, 263:201-205.

16. Pessin JE, Saltiel AR: Signaling pathways in insulin action: molecular targets of insulin resistance. J Clin Invest 2000, 106:165-170.

17. Pirola L, Johnston A, Van Obberghen E: Modulation of insulin action. Diabetologia 2004, 47:170-184.

18. Saltiel AR, Kahn CR: Insulin signalling and the regulation of glucose and lipid metabolism. Nature 2001, 414:799-806.

19. Guller S, Corin RE, Mynarcik DC, London BM, Sonenberg M: Role of insulin in growth hormone-stimulated 3T3 cell adipogenesis. Endocrinology 1988, 122:2084-2089.

20. Rabinowitz D, Klassen GA, Zierler KL: Effect of human growth hormone on muscle and adipose tissue metabolism in the forearm of man. J Clin Invest 1965, 44:51.

21. J-O J, Eden S, Isaksson O: Sexual dimorphism in the control of growth hormone secretion. Endocr Rev 1985, 6:128-150

22. Takano A, Haruta T, Iwata M, Usui I, Uno T, Kawahara J, Ueno E, Sasaoka T, Kobayashi M: Growth hormone induces cellular insulin resistance by uncoupling phosphatidylinositol 3-kinase and its downstream signals in 3T3-L1 adipocytes. Diabets 2001, 50:1891-1900.

23. Wang X, Yang N, Deng L, Li X, Jiang J, Gan Y, Frank SJ: Interruption of growth hormone signaling via SHC and ERK in 3T3-F442A preadipocytes upon knockdown of insulin receptor substrate-1. Mol Endocrinol 2009, 23:486-496.

24. Yang N, Huang Y, Jiang J, Frank SJ: Caveolar and lipid raft localization of the growth hormone receptor and its signaling elements. J Biol Chem 2004, 279:20898-20905.
25. Vainio S, Heino S, Månsson J-E, Fredman P, Kuismanen E, Vaarala O, Ikonen E: Dynamic association of human insulin receptor with lipid rafts in cells lacking caveolae. EMBO Rep 2002, 3:95-100

26. Huang Y, Kim S-O, Yang N, Jiang J, Frank SJ: Physical and functiona interaction of growth hormone and insulin-like growth factor-I signaling elements. Mol Endocrinol 2004, 18:1471-1485.

doi:10.1186/1476-511X-12-56

Cite this article as: Zhang et al:: Effects of insulin and IGF-I on growth hormone- induced STAT5 activation in 3T3-F442A adipocytes. Lipids in Health and Disease 2013 12:56.

\section{Submit your next manuscript to BioMed Central and take full advantage of:}

- Convenient online submission

- Thorough peer review

- No space constraints or color figure charges

- Immediate publication on acceptance

- Inclusion in PubMed, CAS, Scopus and Google Scholar

- Research which is freely available for redistribution

Submit your manuscript at www.biomedcentral.com/submit
C) Biomed Central 